\title{
Effective Antioxidant activity of Phytic acid Prevents Isoproterenol-Induced Myocardial Infarction in Albino wistar Rats
}

E BRINDHA ( $\square$ drbrindha.e@kahedu.edu.in ) KARPAGAM ACADEMY OF HIGHER EDUCATION https://orcid.org/0000-0002-5383-4207

\section{Research Article}

Keywords: Phytic acid, Isoproterenol, Myocardial infarction, Cardiac markers, Oxidative stress, Free radicals

Posted Date: November 19th, 2021

DOI: https://doi.org/10.21203/rs.3.rs-1055110/v1

License: (c) (i) This work is licensed under a Creative Commons Attribution 4.0 International License. Read Full License 


\section{Abstract}

This study aimed to evaluate the preventive effect of phytic acid on cardiac markers, blood glucose, total proteins, albumin/globulin (A/G) ratio, serum uric acid, serum iron, and plasma iron binding capacity in isoproterenol (ISO)-induced myocardial infarction (MI) in male Wistar rats. Rats subcutaneously injected with ISO ( $85 \mathrm{mg} / \mathrm{kg})$ at an interval of $24 \mathrm{~h}$ for 2 days showed a significant increase in the degrees of cardiac troponin $\mathrm{T}(\mathrm{cTnT})$, intensity of the bands of lactate dehydrogenase (LDH)-isoenzyme (LDH1 and $\mathrm{LDH} 2$ ) and the activities of cardiac marker enzymes such as creatine kinase-MB (CK-MB), creatine kinase (CK), lactate dehydrogenase (LDH), aspartate transaminase (AST) and alanine transaminase (ALT) in serum with subsequent decrease in the activities of CK, LDH, AST and ALT in the heart. ISO-induced rats showed a significant increase in blood glucose, serum uric acid, serum iron and a decrease in the levels of total proteins, A/G ratio and iron binding capacity. Pretreatment with phytic acid ( 25 and $50 \mathrm{mg} / \mathrm{kg}$ ) daily for a period of 56 days positively altered the levels of cTnT, intensity of the bands of the LDH1 and LDH2-isoenzyme and the activities of cardiac marker enzymes, and other biochemical parameters. Thus, phytic acid possess cardioprotective effect in ISO-induced oxidative stress in rats.

\section{Introduction}

Solid human existence is consistently cardinal for person beginning from his introduction to the world to for the duration of life. Number of illnesses assumes a vital part in upsetting the solid human existence. It is straightforwardly or by implication faces challenge from a few infections coming about at some point in endurance and in some cases in give up to illnesses. Cardiovascular sickness (CVD), stay the chief reason for death in both created and agricultural nations. It might present as an average 'cardiovascular failure', as abrupt passing, or it could be distinguished at a high level stage and be depicted as a quiet infarct. CVD incorporates hypertension, coronary illness, congestive cardiovascular breakdown, stroke and records for $17,000,000$ passings for each annum overall [1]. Among a few potential causative variables, single nucleotide changes in the key record factors are vital in contributing the event of CHD. FOG2, a transcriptional cofactor of GATA4, is notable quality which is communicated at early cardiovascular improvement in heart tissues [2]. Changes in the coding district of this quality have been accounted for as possible causative specialist for different CHD aggregates [3].

Isoproterenol (ISO), an engineered catecholomine and $\beta$-adrenergic agonist organization causes serious pressure in the myocardium [4]. Different systems has put sent to clarify the ISO-prompted MI. Autooxidation of catecholamine prompts age of free extremists that harms the myocardium is the most acknowledged one. Organization of ISO joined by hyperglycemia, hyperlipidemia and expansion in heart marker catalysts like imaginative kinase (CK), lactate dehydrogenase (LDH), aspartate transaminase (AST) and alanine transaminase (ALT) in serum.

Phenolic intensifies structure a generous piece of plant food varieties and an essential job in human wellbeing. The majority of these phenolic compounds are cell reinforcements, which might ensure against CVD [5]. Phenolic acids have gotten a lot of consideration as a result of their job in the avoidance 
of numerous human illnesses, especially atherosclerosis and malignancy because of their cancer prevention agent properties [6]. Phytic acid (myo-inositol hexaphosphate, IP6) is broadly found in grains, nuts, vegetables, oil seeds, dust, and spores. Nonetheless, as of late, phytic acid has been accounted for to be a cell reinforcement [7] anticarcinogenic [8] and hypoglycemic or hypolipidemic [9] impacts.

A past logical report has shown that phytic acid represses oxidation of low-thickness lipoprotein in vitro and may hence secure against CVD [10]. A definite report is important to know, regardless of whether the cell reinforcement movement of phytic acid assumes any part in the lipid peroxide - intervened heart harm in MI. In this specific circumstance, an endeavor has been made to decide defensive impact of phytic acid in ISO-instigated cardiovascular harm regarding heart catalysts and other biochemical boundaries.

\section{Materials And Methods}

\section{Test creatures and diet}

Every one of the analyses were performed with male Albino Wistar rats (Rattus norvegicus) weighing 170$200 \mathrm{~g}$ acquired from the Central Animal House, Rajah Muthiah Institute of Health Sciences, Annamalai University, Tamil Nadu, India. They were housed in polypropylene confines $(47 \mathrm{~cm} \times 34 \mathrm{~cm} \times 20 \mathrm{~cm})(4$ rats for each enclosure) fixed with husk, recharged like clockwork under a 12:12-hour light-dim cycle at around $22^{\circ} \mathrm{C}$ and had free admittance to tap water and food. The rats were benefited from a standard pelleted diet (Pranav Agro Industries, Maharashtra, India). The analysis was completed by the rules of the Committee with the end goal of Control and Supervision of Experiments on Animals, New Delhi, India, and endorsed by the Animal Ethical Committee of Bharathidasan University (Approval No.

BDU/IAEC/2011/31/29.03.2011).

\section{Drug and chemicals}

Phytic acid, isoproterenol hydrochloride, butylated hydroxyl toluene, nitroblue tetrazolium, phenazine metho sulfate, glutathione, nicotinamide adenine dinucleotide, and 1-chloro-2,4-dinitrobenzene were purchased from Sigma Chemical, St Louis, MO, USA. All the other chemicals used in this study were of analytical grade.

\section{Acceptance of exploratory myocardial dead tissue}

Isoproterenol $(85 \mathrm{mg} / \mathrm{kg})$ was broken down in ordinary saline and subcutaneously infused to rats at time frames $\mathrm{h}$ for 2 days [3]. ISO-initiated MI was affirmed by raised exercises of serum creatine kinase, creatine kinase $-\mathrm{MB}$ and lactate dehydrogenase in rats.

\section{Study plan}

In this test, a sum of 36 rats were utilized. Six rats were utilized in each gathering. The six gatherings were as per the following: Group I: Normal control rats; Group II, and III: Normal rats treated with phytic acid (25 and $50 \mathrm{mg} / \mathrm{kg}$ individually); Group IV: ISO (85 mg/kg) control rats, Group V and VI: Rats pretreated with 
phytic acid (25 and $50 \mathrm{mg} / \mathrm{kg}$ separately) and afterward subcutaneously infused with ISO. Phytic acid was broken up in water and directed to rats orally utilizing an intragastric tube day by day for a time of 56 days.

Toward the finish of the trial time frame, following $12 \mathrm{~h}$ of second ISO-infusion, every one of the rats were forfeited by cervical beheading. Blood was gathered in two distinct cylinders, i.e., one with anticoagulant for the division of plasma and one more without anticoagulant for the serum. Plasma and serum were isolated by centrifugation and utilized for different biochemical assessments.

\section{Handling of heart tissue}

The heart tissue was extracted quickly from the creatures, washed off blood with ice-chilled physiological saline and put away for additional biochemical assessment. A known weight $(200 \mathrm{mg})$ of the heart tissue was homogenized in $5 \mathrm{ml}$ of $0.1 \mathrm{M}$ Tris- $\mathrm{HCl}(\mathrm{PH}-7.4)$ support arrangement. The homogenate was centrifuged at $3000 \mathrm{rpm}$ for $5 \mathrm{~min}$ [11]. The supernatant was utilized for the assessment of different biochemical boundaries.

\section{Biochemical tests}

\section{Assessment of cTnT and test of CK-MB}

The degrees of cTnT in serum were assessed utilizing a standard unit by electro chemiluminescence immunoassay (Catalog no. 12017423, Roche Diagnostics, Switzerland). CK-MB action was examined in serum utilizing a business unit (Product no. 11207001) got from Agappe Diagnostics, Kerala, India.

\section{Division and measurement of LDH-isoenzymes}

LDH-isoenzymes were isolated by agarose gel electrophoresis [12]. Agarose gel (1\%) was ready and applied promptly to the glass slide. After the gel sets appropriately, $10 \mu \mathrm{l}$ of serum tests were applied into wells. After the run, the gels were eliminated and stained by the accompanying strategy. The staining arrangement contained $1.0 \mathrm{ml}$ of $1 \mathrm{M}$ lithium lactate, $1.0 \mathrm{ml}$ of $1 \mathrm{M}$ sodium chloride, $1.0 \mathrm{ml}$ of $5 \mathrm{mM}$ magnesium chloride, $2.5 \mathrm{ml}$ of $0.1 \%$ nitroblue tetrazolium, $0.25 \mathrm{ml}$ of $0.1 \%$ phenazine methosulphate, 2.5 $\mathrm{ml}$ of $0.5 \mathrm{M}$ phosphate cradle $(\mathrm{pH} \mathrm{7.5)}$ ) and $10 \mathrm{mg}$ of NAD in an all out volume of $10 \mathrm{ml}$. The gels were hatched with the staining arrangement at $37 \circ \mathrm{C}$ in obscurity for an appropriate period. The gels were washed with acidic acid (7.5\%) and saved in $5 \%$ acidic acid.

Exercises of creatine kinase-MB (CK-MB) and lactate dehydrogenase (LDH) were estimated in the serum utilizing standard business units. The plasma iron restricting limit was dictated by the strategy for Ramsay [13]. A $4.0 \mathrm{ml}$ of ferric chloride was added to $2.0 \mathrm{ml}$ of plasma. In the wake of representing $5 \mathrm{~min}$, $400 \mathrm{mg}$ of magnesium carbonate was added and blended well. The blend was hatched for one hour at room temperature with regular shaking. The substance were centrifuged and $4.0 \mathrm{ml}$ of supernatant was taken for the assessment of iron [14].

\section{Assay of marker enzymes}


Action of CK was tested in serum and the heart tissue by the strategy for Okinaka et al. [15]. Around 0.75 $\mathrm{ml}$ of twofold refined water, $0.05 \mathrm{ml}$ of test, $0.1 \mathrm{ml}$ of ATP, $0.1 \mathrm{ml}$ of magnesium-cystine reagent and 0.1 $\mathrm{ml}$ of creatine $(240 \mathrm{mM})$ containing tubes were hatched at $37 \circ \mathrm{C}$ for $20 \mathrm{~min}$. The cylinders were centrifuged and the supernatant was utilized for the assessment of phosphorus by Fiske and Subbarow [16] strategy. Around $1.0 \mathrm{ml}$ of the supernatant was made up to $4.0 \mathrm{ml}$ with refined water and added 1.0 $\mathrm{ml}$ of $2.5 \%$ ammonium molybdate. This was brooded at room temperature for $10 \mathrm{~min}$ and $0.4 \mathrm{ml}$ of ANSA was added. The tone created was perused spectrophotometrically at $640 \mathrm{~nm}$ after $20 \mathrm{~min}$.

The action of lactate dehydrogenase was examined by the technique for Buhl and Jackson [17]. Lactate dehydrogenase catalyzes the change of lactate to pyruvate and the measure of pyruvate shaped are estimated at $340 \mathrm{~nm}$ (Qualigens diagnostics, Product No. 72141, Mumbai, India). The exercises of AST and ALT (Product Nos. 72141 and 72).

Glucose levels were estimated by glucose oxidase/ peroxidase method using a commercial kit. Uric acid in serum (Product No. 72171) and total proteins and $A / G$ ratio levels in plasma were estimated using commercial kits (Product No. 72111) obtained from Qualigens Diagnostics, Mumbai, India.

Serum iron content was estimated by the method of Ramsay [11]. Equal volumes of serum, $0.1 \mathrm{M}$ sodium sulphite and dipyridyl reagent were mixed in glass stoppered centrifuge tubes. The tubes were heated in a boiling water bath for $5 \mathrm{~min}$. The contents were cooled and $12.0 \mathrm{ml}$ of chloroform was added in each tube. The tubes were stoppered and mixed vigorously for $30 \mathrm{~s}$ and centrifuged for $5 \mathrm{~min}$ at $1000 \mathrm{rpm}$. The colour intensity was measured at $520 \mathrm{~nm}$.

The plasma iron binding capacity was determined by the method of Ramsay [11]. A $4.0 \mathrm{ml}$ of ferric chloride was added to $2.0 \mathrm{ml}$ of plasma. After standing for $5 \mathrm{~min}, 400 \mathrm{mg}$ of magnesium carbonate was added and mixed well. The mixture was incubated for one hour at room temperature with frequent shaking. The contents were centrifuged and $4.0 \mathrm{ml}$ of supernatant was taken for the estimation of iron.

\section{Statistical Analysis}

Statistical analysis was carried out by one way analysis of variance (ANOVA) followed by Duncan's Multiple Range Test (DMRT) using SPSS software package, version 9.05. P values $<0.05$ were considered as significant, all the results expressed as mean \pm S.D for 6 rats in each group.

\section{Results}

Table 1 shows the levels of serum cTnT and the activity of serum CK-MB in normal and experimental rats. Rats treated with ISO-showed a significant $(P<0.05)$ increase in the levels of CTnT and the activity of CKMB in serum when compared to normal control rats. Pretreatment with phytic acid ( 25 and $50 \mathrm{mg} / \mathrm{kg}$, respectively) daily for a period of 56 days significantly $(P<0.05)$ decreased the levels of cTnT and the activity of CK-MB in serum in ISO-induced rats. 
Table 1

Effect of phytic acid on the levels of cardiac troponin T (cTnT) and the activity of creatine kinase-MB (CK-MB) in serum in normal and isoproterenol (ISO)-induced myocardial infarction (MI) in rats.

\begin{tabular}{|lll|}
\hline Groups & CK-MB (IU/L) & CTnT $(\mathrm{ng} / \mathrm{ml})$ \\
\hline Normal control & $182.1 \pm 10.08^{\mathrm{a}}$ & $94.4 \pm 5.0^{\mathrm{a}}$ \\
\hline Normal + phytic acid $(25 \mathrm{mg} / \mathrm{kg})$ & $183.4 \pm 13.50^{\mathrm{a}}$ & $93.2 \pm 4.7^{\mathrm{a}}$ \\
\hline Normal + phytic acid $(50 \mathrm{mg} / \mathrm{kg})$ & $179.0 \pm 10.01^{\mathrm{a}}$ & $95.4 \pm 5.7^{\mathrm{a}}$ \\
\hline ISO $(85 \mathrm{mg} / \mathrm{kg})$ control & $392.3 \pm 20.92^{\mathrm{b}}$ & $206.7 \pm 10.0^{\mathrm{b}}$ \\
\hline phytic acid $(25 \mathrm{mg} / \mathrm{kg})+$ ISO & $266.0 \pm 17.20^{\mathrm{C}}$ & $140.3 \pm 9.6^{\mathrm{C}}$ \\
\hline phytic acid $(50 \mathrm{mg} / \mathrm{kg})+$ ISO & $222.1 \pm 18.30^{\mathrm{d}}$ & $105.0 \pm 9.1^{\mathrm{d}}$ \\
\hline
\end{tabular}

Each value is mean \pm S.D. for six rats in each group.

values not sharing a common letter $(a-d)$ differ significantly with each other

$(P<0.05, \mathrm{DMRT})$.

Tables 2 and 3 represent the effect of phytic acid on the activities of serum and the heart CK, LDH, AST and ALT in normal and ISO-induced rats. Rats induced with ISO, showed a significant $(P<0.05)$ increase in the activities of these enzymes in serum and decrease in heart. Pretreatment with phytic acid ( 25 and $50 \mathrm{mg} / \mathrm{kg}$, respectively) significantly $(P<0.05)$ minimized the alterations in the activities of these enzymes in ISO-induced rats.

Table 2

Effect of phytic acid on the activities of creatine kinase (CK), lactate dehydrogenase (LDH), aspartate transaminase (AST) and alanine transaminase (ALT) in serum in normal and isoproterenol (ISO)-induced myocardial infarction (MI) in rats.

\begin{tabular}{|lllll|}
\hline Groups & CK (IU/L) & LDH (IU/L) & AST (IU/L) & ALT (IU/L) \\
\hline Normal control & $222.38 \pm 12.88^{\mathrm{a}}$ & $112.80 \pm 7.48^{\mathrm{a}}$ & $31.60 \pm 1.98^{\mathrm{a}}$ & $21.29 \pm 1.28^{\mathrm{a}}$ \\
\hline Normal + phytic acid $(25 \mathrm{mg} / \mathrm{kg})$ & $218.92 \pm 16.06^{\mathrm{a}}$ & $111.28 \pm 8.30^{\mathrm{a}}$ & $30.88 \pm 2.33^{\mathrm{a}}$ & $19.18 \pm 1.38^{\mathrm{a}}$ \\
\hline Normal + phytic acid $50 \mathrm{mg} / \mathrm{kg})$ & $218.38 \pm 12.45^{\mathrm{a}}$ & $110.02 \pm 7.38^{\mathrm{a}}$ & $30.95 \pm 2.01^{\mathrm{a}}$ & $19.01 \pm 1.15^{\mathrm{a}}$ \\
\hline ISO $(85 \mathrm{mg} / \mathrm{kg})$ control & $428.27 \pm 23.01^{\mathrm{b}}$ & $180.52 \pm 12.67^{\mathrm{b}}$ & $60.96 \pm 3.24^{\mathrm{b}}$ & $34.08 \pm 2.06^{\mathrm{b}}$ \\
\hline phytic acid $(25 \mathrm{mg} / \mathrm{kg})+$ ISO & $307.13 \pm 21.56^{\mathrm{c}}$ & $135.62 \pm 9.81^{\mathrm{c}}$ & $41.70 \pm 2.90^{\mathrm{c}}$ & $24.36 \pm 1.92^{\mathrm{c}}$ \\
\hline phytic acid $(50 \mathrm{mg} / \mathrm{kg})+$ ISO & $254.78 \pm 17.54^{\mathrm{d}}$ & $124.71 \pm 7.32^{\mathrm{d}}$ & $35.40 \pm 2.66^{\mathrm{d}}$ & $21.97 \pm 1.48^{\mathrm{d}}$ \\
\hline
\end{tabular}


Each value is mean $\pm S$.D. for six rats in each group.

Values not sharing a common superscript $(a-d)$ differ significantly with each other $(P<0.05, \mathrm{DMRT})$.

Table 3

Effect of phytic acid on the activities of creatine kinase (CK), lactate dehydrogenase (LDH), aspartate transaminase (AST) and alanine transaminase (ALT) in the heart in normal and isoproterenol (ISO)-induced myocardial infarction (MI) in rats

\begin{tabular}{|lllll|}
\hline Groups & CK & LDH & AST & ALT \\
\hline Normal control & $19.01 \pm 1.07^{\mathrm{a}}$ & $95.98 \pm 5.88^{\mathrm{a}}$ & $46.01 \pm 2.75^{\mathrm{a}}$ & $20.11 \pm 1.13^{\mathrm{a}}$ \\
\hline Normal + phytic acid $(25 \mathrm{mg} / \mathrm{kg})$ & $17.82 \pm 1.28^{\mathrm{a}}$ & $96.67 \pm 1.12^{\mathrm{a}}$ & $45.48 \pm 2.20^{\mathrm{a}}$ & $19.83 \pm 1.28^{\mathrm{a}}$ \\
\hline Normal + phytic acid $50 \mathrm{mg} / \mathrm{kg})$ & $18.06 \pm 1.02^{\mathrm{a}}$ & $96.31 \pm 4.01^{\mathrm{a}}$ & $45.48 \pm 1.87^{\mathrm{a}}$ & $19.97 \pm 1.19^{\mathrm{a}}$ \\
\hline ISO $(85 \mathrm{mg} / \mathrm{kg})$ control & $10.11 \pm .15^{\mathrm{b}}$ & $59.98 \pm 4.11^{\mathrm{b}}$ & $22.58 \pm 1.30^{\mathrm{b}}$ & $10.81 \pm 0.12^{\mathrm{b}}$ \\
\hline phytic acid $(25 \mathrm{mg} / \mathrm{kg})+$ ISO & $13.79 \pm 1.02^{\mathrm{c}}$ & $80.915 \pm .79^{\mathrm{c}}$ & $32.01 \pm 2.31^{\mathrm{c}}$ & $15.91 \pm 1.08^{\mathrm{c}}$ \\
\hline phytic acid $(50 \mathrm{mg} / \mathrm{kg})+$ ISO & $15.31 \pm .02^{\mathrm{d}}$ & $88.43 \pm 4.15^{\mathrm{d}}$ & $40.36 \pm 2.42^{\mathrm{d}}$ & $16.45 \pm 1.03^{\mathrm{d}}$ \\
\hline
\end{tabular}

Each value is mean $\pm S$.D. for six rats in each group.

Values not sharing a common superscript $(a-d)$ differ significantly with each other $(P<0.05, \mathrm{DMRT})$.

CK activity: $\mathrm{nmol}$ of phosphorus liberated/min/mg protein. LDH, AST and ALT activity: nmol of pyruvate liberated/min/mg protein.

Table 4 depicts the levels of blood glucose, plasma total proteins and A/G ratio in normal and ISOinduced rats. In ISO-induced rats, the levels of blood glucose was increased significantly $(P<0.05)$ and the levels of plasma total protein and $A / G$ ratio were decreased. Oral pretreatment with phytic acid (25 and $50 \mathrm{mg} / \mathrm{kg}$, respectively) to ISO-induced rats significantly decreased the levels of blood glucose and increased the levels of plasma total protein and $A / G$ ratio in ISO induced rats. 
Table 4

Effect of phytic acid on the levels of blood glucose, plasma total proteins and albumin/globulin (A/G) ratio in normal and isoproterenol (ISO)-induced myocardial infarction (MI) in rats

\begin{tabular}{|llll|}
\hline Groups & $\begin{array}{l}\text { Blood glucose } \\
(\mathrm{mg} / \mathrm{dl})\end{array}$ & $\begin{array}{l}\text { Plasma total } \\
\text { proteins }(\mathrm{g} / \mathrm{dl})\end{array}$ & A/G ratio \\
\hline Normal control & $74.69 \pm 5.20^{\mathrm{a}}$ & $6.71 \pm 0.32^{\mathrm{a}}$ & $1.37 \pm 0.07^{\mathrm{a}}$ \\
\hline Normal + phytic acid $(25 \mathrm{mg} / \mathrm{kg})$ & $73.98 \pm 3.83^{\mathrm{a}}$ & $6.74 \pm 0.27^{\mathrm{a}}$ & $1.38 \pm 0.07^{\mathrm{a}}$ \\
\hline Normal + phytic acid $(50 \mathrm{mg} / \mathrm{kg})$ & $72.96 \pm 5.65^{\mathrm{a}}$ & $6.60 \pm .35^{\mathrm{a}}$ & $1.38 \pm 0.06^{\mathrm{a}}$ \\
\hline ISO $(85 \mathrm{mg} / \mathrm{kg})$ control & $146.63 \pm 8.13^{\mathrm{b}}$ & $4.76 \pm 0.30^{\mathrm{b}}$ & $0.67 \pm 0.04^{\mathrm{b}}$ \\
\hline Phytic acid $(25 \mathrm{mg} / \mathrm{kg})+\mathrm{ISO}$ & $107.31 \pm 6.36^{\mathrm{c}}$ & $5.80 \pm 0.41^{\mathrm{c}}$ & $1.11 \pm 0.08^{\mathrm{c}}$ \\
\hline Phytic acid $(50 \mathrm{mg} / \mathrm{kg})+\mathrm{ISO}$ & $86.40 \pm 4.45^{\mathrm{d}}$ & $6.26 \pm 0.27^{\mathrm{d}}$ & $1.23 \pm 0.07^{\mathrm{d}}$ \\
\hline
\end{tabular}

Value is mean \pm S.D. for six rats in each group.

Values not sharing a common superscript $(a-d)$ differ significantly with each other $(P<0.05, \mathrm{DMRT})$.

Table 5 shows the levels of serum uric acid, iron and plasma iron binding capacity in normal and ISOinduced rats. The levels of uric acid and serum iron were increased significantly with subsequent decrease in the levels of plasma iron binding capacity in ISO-induced rats when compared with normal control rats. Phytic acid (25 and $50 \mathrm{mg} / \mathrm{kg}$, respectively) pretreatment to ISO-induced rats significantly minimized these alterations. 
Table 5

Effect of phytic acid on the levels of serum uric acid, serum iron and plasma iron binding capacity in normal and isoproterenol (ISO)-induced myocardial infarction (MI) in rats

\begin{tabular}{|c|c|c|c|}
\hline Groups & $\begin{array}{l}\text { Serum uric acid } \\
(\mathrm{mg} / \mathrm{dl})\end{array}$ & $\begin{array}{l}\text { Serum iron } \\
(\mu \mathrm{g} / \mathrm{dl})\end{array}$ & $\begin{array}{l}\text { Plasma iron binding capacity } \\
(\mu \mathrm{g} / \mathrm{dl})\end{array}$ \\
\hline Normal control & $2.32 \pm 0.12^{\mathrm{a}}$ & $45.21 \pm 2.87^{a}$ & $40.53 \pm 2.52^{\mathrm{a}}$ \\
\hline $\begin{array}{l}\text { Normal + phytic acid (25 } \\
\mathrm{mg} / \mathrm{kg})\end{array}$ & $2.23 \pm 0.15^{a}$ & $44.00 \pm 3.19^{a}$ & $40.08 \pm 2.18^{a}$ \\
\hline $\begin{array}{l}\text { Normal + phytic acid (50 } \\
\mathrm{mg} / \mathrm{kg})\end{array}$ & $2.18 \pm 0.12^{\mathrm{a}}$ & $45.20 \pm 2.05^{a}$ & $41.20 \pm 2.21^{a}$ \\
\hline ISO $(85 \mathrm{mg} / \mathrm{kg})$ control & $4.57 \pm 0.18^{b}$ & $83.81 \pm 5.12^{b}$ & $26.45 \pm 1.64^{\mathrm{b}}$ \\
\hline $\begin{array}{l}\text { Phytic acid }(25 \mathrm{mg} / \mathrm{kg})+ \\
\text { ISO }\end{array}$ & $2.87 \pm 0.15^{c}$ & $63.56 \pm 4.65^{c}$ & $32.54 \pm 2.37^{c}$ \\
\hline $\begin{array}{l}\text { Phytic acid }(50 \mathrm{mg} / \mathrm{kg})+ \\
\text { ISO }\end{array}$ & $2.57 \pm 0.14^{d}$ & $36.0 \pm 3.75^{d}$ & $36.27 \pm 2.66^{d}$ \\
\hline
\end{tabular}

Each Value is mean \pm S.D. for six rats in each group.

Values not sharing a common superscript $(a-d)$ differ significantly with each

other $(P<0.05, \mathrm{DMRT})$.

For all the parameters studied pretreatment with phytic acid $50 \mathrm{mg} / \mathrm{kg}$ showed better effect than phytic acid $25 \mathrm{mg} / \mathrm{kg}$ to ISO-induced rats. Phytic acid treatment to normal rats did not show any significant effect.

\section{Discussion}

The levels of cTnT in serum increased in ISO induced rats. Increased levels of troponin predict the risk of both cardiac death and subsequent infarction. Our results are reliable with a previous report by Acikel et al. [18]. Pretreatment with phytic acid for a period of 56 days significantly decreased the levels of cTnT and CK-MB in serum of ISO-induced rats. This could be due to the reduction of the degree of damage in the myocardium by phytic acid. Assay of the activity of CK-MB in serum is an important diagnosis, because of the marked abundance of this enzyme and virtual absence from most other tissues and its consequent sensitivity. CK-MB isoenzyme activity is useful not only as an indicator of early diagnosis of $\mathrm{MI}$, but any type of myocardial injury. The increased activity of serum CK-MB observed in ISO-induced rats might be due to cardiac damage induced by ISO [19].

Lactate dehydrogenase is a cytosolic enzyme, which is essentially present in all the tissues involved in glycolysis and exists in five different isoforms designated as LDH1-LDH5. In cardiac tissue, LDH1 and 
LDH2 are predominate. Hence, detection of elevated concentration of this enzyme released into the blood stream from the damaged tissue has become a definitive diagnostic and prognostic criterion for various diseases and disorders and a study of its isoenzymes has found importance in the location of tissue damage [20].

In the present study, we have noticed an increment in the force of LDH1 and LDH2-groups in ISO-initiated rats, which is upheld by the past discoveries of Levinson and Hobbs [21]. Voet and Donald [22] have detailed that the arrival of the cardiovascular explicit isoenzymes LDH1 and LDH2-into the flow may be because of the putrefaction instigated by ISO. Phytic acid pretreatment to ISO-prompted rats showed a reduction in the movement of CK-MB and the power of LDH1 and LDH2-groups and densitometric check tops in ISO-incited rats. This could be because of the defensive impact of phytic acid in myocardium subsequently forestalling the spillage of CK-MB and LDH.

Serum CK, AST, ALT and LDH are notable markers of MI. At the point when myocardial cells are harmed or obliterated because of inadequate oxygen supply or glucose, the heart film becomes penetrable or may break, which brings about spillage of compounds. These chemicals go into the circulatory system hence expanding their fixation in the serum [23]. Exercises of these proteins in serum diminished in phytic acid pretreated ISO-actuated gathering likely because of the defensive impact of phytic acid on myocardium, which had decreased the degree of myocardial harm instigated by ISO and accordingly confining the spillage of these compounds from myocardium.

ISO-administration is related with articulated metabolic anomalies in blood glucose levels. Expansion in the degrees of blood glucose was seen in ISO-incited rats. An increment in the degrees of blood glucose in ISO-actuated rats is because of the upgraded glycogen separate and less usage by the fringe tissues in $\mathrm{MI}$ in rats [24]. Pretreatment with phytic acid fundamentally diminished the degrees of blood glucose in ISO-instigated rats. An in vivo study has exhibited that phytic acid evokes critical improvement of hyperglycemia in streptozotocin-instigated diabetic rats [25].

A diminishing in the degrees of plasma all out proteins and A/G proportion saw by us in ISO-initiated rats could be because of exorbitant convergence of free extreme creation by ISO. Pretreatment with phytic acid essentially expanded the degrees of plasma all out proteins and A/G proportion [26]. This could be because of the capacity of phytic acid to rummage free extremists and to restrain lipid peroxidation.

We have observed a huge expansion in the degrees of serum uric acid in ISO-prompted rats. During hypoxia in the myocardium, ATP consumption happens, which prompts aggregation of hypoxanthine. Xanthine oxidase catalyzes the transformation of hypoxanthine to xanthine, uric acid and superoxide. The dehydrogenase to oxidase transformation happens in ischemic or hypoxic tissue [27]. This could be one reason for the raised degrees of serum uric acid in ISO-prompted rats. Pretreatment with phytic acid altogether diminished the degrees of serum uric acid in ISO-initiated rats.

Conspicuous degrees of serum iron and diminished plasma iron restricting limit were seen in ISO-initiated rats. Heme iron is straightforwardly related and complete iron-restricting limit is conversely identified with 
the danger of MI [28]. During ischemia, free iron is unconfined from heme-subordinate proteins like hemoglobin and myoglobin and diminishes iron restricting limit and in this manner expands prostaglandin digestion and in vivo lipid peroxidation. Oral pretreatment with phytic acid to ISO-prompted rats diminished the degrees of serum iron and expanded the plasma iron restricting limit. This impact may be because of the free extremist searching and cell reinforcement property of phytic acid. Cell reinforcement movement of phytic acid is because of its chelating capacity of iron [29]. In addition, the expanded plasma iron restricting might have forestalled hemolysis and iron catalyzed lipid peroxidation.

Taking everything into account, phytic acid, detached the myocardium against ISO-incited heart harm by keeping up with the cardiovascular marker and other biochemical boundaries by searching free revolutionaries, and its cancer prevention agent impact. The aftereffects of our review show that phytic acid is a powerful and safe cancer prevention agent in creature models. The consequences of the current examination might produce a reestablished interest in the utilization of phytic acid for MI.

\section{Declarations}

\section{ETHICAL PROCEDURE}

- The research meets all applicable standards with regard to the ethics of experimentation and research integrity, and the following is being certified/declared true.

- As an expert scientist, the paper has been submitted with full responsibility, following due ethical procedure, and there is no duplicate publication, fraud, plagiarism, or concerns about animal or human experimentation.

\section{A DISCLOSURE / CONFLICT OF INTEREST STATEMENT}

- None of the authors of this paper has a financial or personal relationship with other people or organizations that could inappropriately influence or bias the content of the paper.

- It is to specifically state that "No Competing interests are at stake and there is No Conflict of Interest" with other people or organizations that could inappropriately influence or bias the content of the paper.

\section{References}

1. Acikel M, Buyukokuroglu ME, Erdogan F, Aksoy H, Bozkurt E, Senocak H (2005) Protective effect of dandroline against myocardial injury induced by isoproterenol in rats: biochemical and histological findings. Int J Cardiol 98:389-394.

2. Crispino JD, Lodish MB, Thurberg BL, Litovsky SH, Collins T, Molkentin JD (2001) Proper coronary vascular development and heart morphogenesis depend on interaction of GATA-4 with FOG cofactors. Genes Dev 15(7):839-8444. 
3. Brindha E, Mutational analysis of FOG2 gene in patients with congenital Heart disease (2020) Gene Technol 9 Iss.2 No:1000150 9:2. Doi: 10.24015/2329-6682.20.9.150.

4. Ahmed KK, Rana, AC, Dixit VK (2004) Effect of Caltropis procera latex on isoproterenol induced myocardial infarction in albino rats. Phytomedicine 11:327-330.

5. Ascherio A, Willett WC, Rimm EB, Giovannucci EL, Stampfer MJ (1994) Dietary iron intake and risk of coronary disease among men. Circulation 89:969-974.

6. Brian Q, Phillippy, Ernst G (199) Antioxidant functions of inositol 1,2,3-triphosphate and inositol 1,2,3,6tetrakisphosphate. Free Radic Biol Med 22:939-946.

7. Brindha E, Rajasekapandiyan M (2015) Preventive effect of phytic acid on lysosomal hydrolases in normal and isoproterenol-induced myocardial infarction in Wistar rats.Toxicol Mech Methods 5:1-20.

8. El-Rahman ABD AA, El-Naem ABD, El-Shafei MA, and El-Morsi EA (2007) Effect of phytic acid on liver and kidneys weight and some biochemical parameters in

albino rats treated with Aflatoxin $B_{1}$. Af Crop Sci 8:1765-1772.

9. Fiske $\mathrm{CH}$, Subbarow $\mathrm{Y}$ (1925) The colorimetric determination of phosphorus. J Biol Chem 66:375-400.

10. Graf E, Eaton JW (1990) Antioxidant functions of phytic acid. Free Radic Biol Med 8:61-69.

11. Jung UJ, Lee MK, Jeong KS, Choi MS (2004) The hypoglycemic effect of hesperidin and naringin are partly mediated by hepatic glucose-regulating enzymes in C57BL/Ks-db/db mice. J Nut 134: 2499-2503.

12. Levinson SS, Hobbs GA (1994) Usefulness of various lactate of various dehydrogenase isoenzyme profiles after myocardial infarction. Ann Clin Lab Sci 24:364-370.

13. Mathew S, Menon PV, Kurup PA (1985) Effect of administration of vitamin A, ascorbic acid and nicotinamide adnine dinucleotide + flavin adenine dinucleotide on

severity of myocardial infarction induced by isoproternol in rats. Indian J Ex Biol

23(9):500-504.

14. Mattila P, Kumpulainen J (2002) Determination of free and total phenolic acids in plant-derived foods by high performance liquid chromatography with diode-array

detection. J Agric Food Chem 50: 3660-3667.

15. Mc Cord JM (1988) Free radicals and myocardial ischemia Free Radic Biol Med.

4:9-14.

Page $12 / 14$ 
16. Mckenzie D, Henderson AR (1983) Electrophoresis of lactate dehydrogenase isoenzyme ClinChem. 29:189-195.

17. Miayamoto S, Kuwata G, Imai M, Nagao A, Terao J (2005) Protective effect of phytic acid hydrolysis products on iron-induced lipid peroxidation of liposomal

membranes. Lipids 35(12):1411-1413.

18. Nardini M, D'Aquino M, Tomassi G, Gentili V, Di-Felice M, Scaccini C (1995)

Inhibition of human low-density lipoprotein oxidation by caffeic acid and other

hydroxycinnamic acid derivatives. Free Radic Biol Med 19:541-552.

19. Okinaka S, Kumagai H, Ebashi S (1961) Serum creatine phosphokinase Activity

in progressive muscular dystrophy and neuromuscular diseases. Arch Neurol

4:520-525.

20. Padmanabhan M, Stanely Mainzen Prince P (2006) Preventive effect of S-allylcysteine on lipid peroxides and antioxidants in normal and isoproterenol-induced

cardiotoicity in rats: A histopathological study. Toxicology 224:128-137.

21. Plaa GL, Zimmerson HJ (1997) Evaluation of hepatotoxicity: physiological and

biochemical measures of hepatic function. In; M.Cuskey RS, Earnest, DL(Eds.),

comprehensive toxicology Cambridge University Press, Cambridge 97-

109.

22. Prabhu S, Devi CS (2006) Protective effect of mangiferin, an active phytochemical and cardiotonic from Mangifera indica Linno isoproterenol induced myocardial infracted rats- an electrocardiographic, electrophoretic and biochemical evidences. Phcog Mag 2:183-190.

23. Ramsay WNM (1969b) Ramsay's dipyridyl method for iron binding capacity. In: Varley,H. (Ed.), Practical Clinical Chemistry. Heinemann, London, UK 475-

476.

24. Reeve JLV, Duffy AM, O'Brien, T, Samali, A (2005) Don't lose heart therapeutic value of apoptosis prevention in the treatment of cardiovascular disease. J Cell Mol Med 9:609-622. 
25. Rickard SE Thompson LU (1997) Interactions and biological effects of phytic acid. In F. Shahidi (Ed.), ACS symposium series: No. 662. Antinutrients and

phytochemicals in food (pp.294-312). Washington, DC: American Chemical

Society.

26. Senthil Kumaran KP, Stanely Mainzen Prince P (2010) Protective effect of caffeic acid on cardiac markers and lipid peroxide metabolism in cardiotoxic rats: an in vivo

and in vitro study. Metab Clin Exp 59:1172-1180.

27. Shamsuddin AM, Vucenik I, Cole KE (1997) IP $_{6}$. novel anti-cancer agent. Life Sci 61:343-354.

28. Voet JG, Donald V (1995) ATP driven active transport. In: textbook of Biochemistry, $2^{\text {nd }}$ ed. John Wiley, New York 524-535.

29. Wexler BC (1978) Myocardial infarction in young vs.old male rats. Pathophysiologic changes. Am Heart J 96:70-80. 